\title{
A Case Study: Implementation of Quality Management System ISO 9001:2008 in Education Institute, Karachi
}

\author{
Sarah Khan ${ }^{1}$, Nabeel Afzaal ${ }^{2}$ \\ ${ }^{I}$ (Hamdard Institute of Education and Social Sciences, Hamdard University, Pakistan) \\ ${ }_{2}^{2}$ (Hamdard Institute of Education and Social Sciences, Hamdard University, Pakistan)
}

\begin{abstract}
Education institute can lose quality education because they fail to adopt significant opportunities to improve their education standard as per Quality Management System guidelines. In order to survive in a competitive market, universities should reduce students and employees dissatisfaction level, by improving the quality and productivity of their services.

The objective of this study is to provide gap analysis for quality management system implemented in a university which gives detailed action plan to overcome problems and issues regarding implementation of "Quality Management System" in universities. In this regard, a research has been conducted to find the reason behind the absence of documented rules and regulations for the employees. The research also seeks the answer for the departmental autonomy observed within the universities. In addition, the report answers various questions regarding the clauses of ISO 9001:2008" Quality Management System" standard without any specific assumptions.

After gap analysis of Quality Management System in one of the reputable university in Karachi, the university received overall rating of "NEED IMPROVEMENT" which suggested the university need to work hard on documentation and policies for students/employees satisfaction.
\end{abstract}

Key Words: Quality management system, Audit, Gap Analysis, Documentation, standardization

\section{Introduction}

Various reasons at universities require implementation of ISO 9001:2008 Quality Management System standard. These are required to enhance awareness in its employees with respect to documented procedure and a proper format for carrying out different functions at various levels. As well as to promote standardization in all departments and students satisfaction [1].

System of education functioning at present in considerable range was designed and shaped in 11th age. In the system of education quality was based on the rule of the mutual confidence and understanding. In the era of the fast development of the higher education, compulsory needs creating the formalized systems assuring the fulfillment of the academic standards.[2-4]

\subsection{QUALITY AT UNIVERSITY:}

Quality in education enables the students to enhance their skills and abilities by implementing the knowledge get through quality education. The students, pupils and teachers need to be treated differently by knowing their respective needs. Quality in education depends on multiple factors and elements.[5].According to quality definition proposed by J.M Juran [5], it can be initially accepted, that the quality of the university is the degree, in which, it fulfills the growing requirements of surroundings and helps in the students' development, at simultaneous care about the solid development of didactic and scientific personnel. Quality in education can be measured through two factors i.e. results and process itself.

A wide view need to be developed on the educational services and on quality. This quality can be visualized through many components which largely contribute in the success of the educational aims. [3] It should be taken into account: the quality of the material potential, the quality of the immaterial potential, the processes quality and the quality of the results. Currently quality education is the critical factor for famous universities and develops an entirely different view of the university management.

$\geq$ Institutions need to design policies and procedures for the assurance of quality and standards. They should commit themselves to the development and progress of the culture which emphasizes on the importance of quality for which institutions should devise and implement a strategy for the enhancement of quality. The strategy and policies should have a formal status and need to be publicly available.

$\geq$ Institutions should need to have a formal policy for the approval, periodic review and monitoring of their programs and awards.

$\geq$ Students should be evaluated using published criteria, regulations and procedures which are applied consistently. 
$\geq$ Institutions should develop multiple ways to satisfy themselves that staff involved with the teaching is qualified and competent.

$\geq$ Institutions should ensure that the resources available for the student learning and development are adequate and appropriate for each program offered.

$\geq$ Institutions need to ensure that they collect, analyze and use relevant information for the effective and timely management of their programs of study and co-curricular activities.

$\geq$ Intuitions should publish impartial information both qualitative and quantitative, on timely basis regarding the programs and awards they are offering [7].

\subsection{QUALITY ISSUES AT UNIVERSITIES:}

$>$ Educational Institution facing number of problems in their process flow and especially in documentation.

$>$ Institution doesn't have any documented procedure and right instructions.

$>$ All departments are working with their own working style.

$>$ Job description of employees is not clearly defined.

$>$ No recruitment and selection criteria exist.

$>$ Library lacks updated edition of books and journals .Number of books available are not enough to meet the requirement of students

\section{Research Methodology}

This research has been carried out with the help of ISO 9001:2008 Quality Management System standard, so we prepared questionnaire (Gap analysis checklist) with the help of standard for our research and made conclusion on the basis of questionnaire result.

The audit scope include following departments;

$>$ Quality enhancement Cell

$>$ Engineering Laboratories

$>$ Administration

$>$ Engineering Department

Questionnaire filled by the management of university.

Research include details of,

- Questionnaire (Gap analysis checklist)

- Audit Findings Report

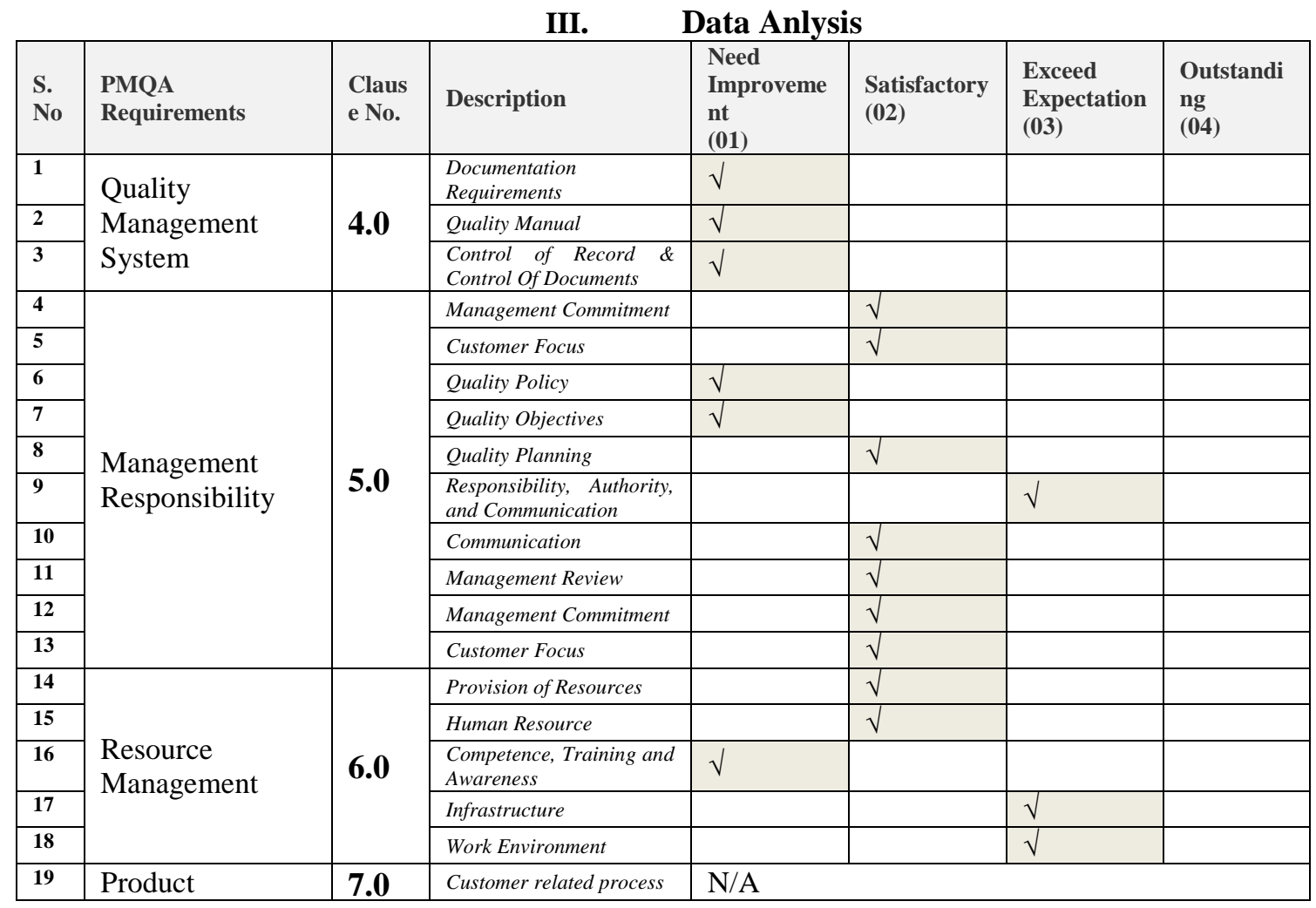


A Case Study: Implementation of Quality Management System ISO 9001:2008 in Education Institute,

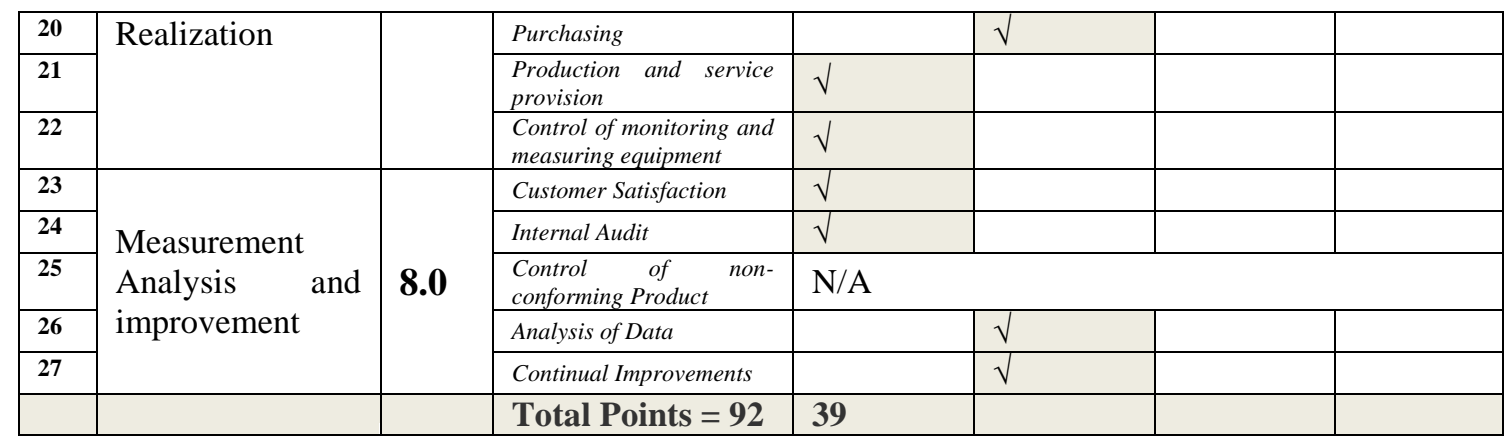

Through analysis, it was ascertained that currently university stands at initial phase or NEED IMPROVEMENT phase. We can assume that it will take time about one and half year for implementation of ISO 9001:2008 standard at institute if they start working from today. As discussed in questionnaire and through top management personal interviews, by focusing on proper documentation and management system, improvement could be guarantted.It was highlighted in questionnaire that, Student feedback form is one of the requirements of ISO standard, this will improve student satisfaction. It is highly suggested that university management should conduct student feedback and satisfaction survey as defined intervals in university.

\subsection{Assessment Criteria}

\begin{tabular}{|c|c|c|c|c|}
\hline $\begin{array}{l}\text { No. } \\
\text { Questions }\end{array}$ & Ranking & $\begin{array}{l}\text { Questions } \\
\text { Ranking }\end{array}$ & Scaling & Status \\
\hline 23 & 1 & 23 & $23-45$ & Need improvement \\
\hline 23 & 2 & 46 & $46-68$ & Satisfactory \\
\hline 23 & 3 & 69 & 69-91 & Exceed Expectation \\
\hline 23 & 4 & 92 & $92 \&$ above & Outstanding \\
\hline
\end{tabular}

\subsection{Summary of Audit}

\section{Results And Discussion}

\begin{tabular}{|c|c|}
\hline Risk Assessment & Non-Conformance \\
\hline PR & $\begin{array}{l}\text { Educational Institution have some procedures, but as per ISO 9001, institutes need to establish some mandatory } \\
\text { procedures such as: } \\
\text { Control over Records, control over documents, control over non-conformity, corrective action, preventive action, and } \\
\text { internal auditing and management review programs. }\end{array}$ \\
\hline PR & Several manual witnessed, like instrument manual but need to establish Quality manual as per QMS requirement. \\
\hline PR & 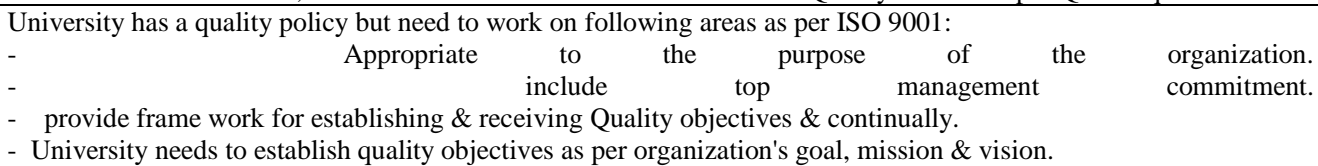 \\
\hline PR & $\begin{array}{l}\text { Training plan of University covers technical related training but need to include some behavioral and ISO related } \\
\text { training in their training plan for effective implementation of ISO standard in university. }\end{array}$ \\
\hline
\end{tabular}

\subsection{Categorizing Audit Findings}

This section outlines the rating definitions used to categorize the non conformances identified during the audit.

Potential Risk (PR): Any finding that has a current or potential high impact on quality (the finding can be isolated or systematic).

Improvement Opportunity (IO): Any low impact finding (isolated or systematic), which is not a structural shortcoming to a quality system element.

Repeat Finding (RF): Any finding identified in the previous audit for which the agreed corrective action has not been completed according to the schedule proposed in the Corrective Action Plan.

\section{Conclusion And Recommendation}

The facility receives the overall rating is "NEED IMPROVEMENT". This will us that the management of university must take some immediate action which were already discuss in Gap Analysis checklist and Audit Finding report. 
Education provides the base for socio-economic development. An education system of poor quality may be one of the most important reasons why poor countries do not grow. The objectives of this study are to provide gap analysis for quality management system implemented in a university. In this regards research has been conducted to find out the reasons behind the absence of documented rules and regulations for the employees.

After a gap analysis of Quality Management System the facility received an overall rating is Need Improvement which suggested that the university need to work hard to get ISO certification. Following are the recommendation for management of university for their improvement in different areas;

$>$ According to clause number 4.2.1 numbers of documents found evident but Quality policy \& Objectives not found documented, Indus need to establish quality policy \& objectives.

$>$ Several manual found like instrument manual but need to establish Quality manual as per QMS requirement.

$>$ Procedure of control document \& record not found evident.

$>$ University needs to establish a quality policy as per clause 5.3 in which; appropriate to the purpose of the organization, include top management commitment, provide frame work for establishing \& receiving Quality objectives \& continually.

$>$ University needs to establish quality objectives as per organization's goal, mission \& vision.

$>$ We have trained people for their technical job but need training in ISO standard.

$>$ Work instruction need to display all working area, Need suitable equipment, and Monitoring \& measurement program.

$>$ Correct use of monitoring a measuring equipment Calibration at required intervals with an authentic / traceable sources.

$>$ Need to conduct customer satisfaction survey.

$>$ Need to establish internal Audit criteria / procedure \& define frequency for internal audit (e.g.) quarterly, annually.

This study achieved its goal, after gap analysis it was identified that Educational Institute laying in NEED IMPROVEMENT stage, Institute need to implement above mentioned recommendations to implement Quality Management System guideline. Institute requires at least one year implementing these recommendations.

\section{Acknowledgment}

In the name of Allah, the Most Gracious and the Most Merciful Alhamdulillah, all praises to Allah for the strengths and His blessing in completing this thesis. Special appreciation goes to my supervisor, Mr Farhan Sharif, for his supervision and constant support. His invaluable help of constructive comments and suggestions throughout the experimental and thesis works have contributed to the success of this research. Not forgotten, my appreciation to my co-supervisor, Mr. Imran Ullah Sharif for his support and knowledge regarding this topic.

Sincere thanks to my chairperson Mr. Saad Ahmed, my colleagues Specially Ms. Shafaq Hanif and Ms.Bushra Akhtar and others for their kindness and moral support during my study. Thanks for the friendship and memories.

Last but not least, my deepest gratitude goes to my beloved parents and also to my sisters for their endless love, prayers and encouragement. Also not forgetting my husband, Mr. Faisal Mehmood for his Support and care. To those who indirectly contributed in this research, your kindness means a lot to me. Thank you very much.

\section{References}

[1] Quality Management System Requirements 9001:2008, Fourth edition 2008-11-15.

[2] M. Winiewska, The attempt of the definition and the implementing model, Quality Problems 9 (2007) 13-22 (in Polish).

[3] http://www.umbrella.org.pl/

[4] M. Piotrowski, Quality in education, ITE, Radom, 1999 (in Polish).

[5] E. Skrzypek, Quality in education - the conditions and factors of the success, Quality Problems 2/2006, 15-20 (in Polish)

[6] J. Michalska, Quality costs' analysis in the selected production process in material engineering, Materials and Technologies 3 (2005) 137-140 (in Polish).

[7] Maria.J Rosa, Claudia S. Sarrico and Alberto Amaral, Implementing Quality Management System in higher Education Institute, centre for research in higher education policies. 